\title{
EFFECT OF CHEMICAL FERTILIZATION AND BIOFERTILIZATION ON GROWTH AND PRODUCTIVITY OF SAVORY (SATUREJA HORTENSIS L.) PLANTS
}

\author{
Wafaa H. Abd-Allah \\ Department of Medicinal and Aromatic Plants, Desert Research \\ Center, Cairo, Egypt \\ E-mail: drwafa414@gmail.com
}

\begin{abstract}
$\mathrm{T}$
he present study was carried out at Menia Governorate (Brotobat village-West Megaga Center, $200 \mathrm{~km}$ from Cairo), during the two successive seasons of 2013 and 2014. The objective of this work was to study the effect of chemical and biofertilizers on growth characters and essential oil productivity of savory (Satureja hortensis L.) plants. From the results, it can be concluded that the combination of full dose of NPK+biofertilizer increased plant height, fresh and dry weights of herb (g/plant) as well as seed index. Moreover, full dose of NPK treatment produced the highest mean values yield per plant and per feddan. It was obvious that, fertilized summer savory plants with biofertilizer only showed its superiority for increasing oil percentage in the seeds. The highest oil yield resulted from the plants fertilized with full dose of NPK+biofertilizer. Whereas, the lowest content was produced from treated plants with biofertilizer only. The main component of oil is carvacrol, which was the highest constituent. As for the effect of applied treatments on oil constituents, it is clear that application of biofertilizer alone decreased carvacrol percentage since it was $45.66 \%$ comparing to other applied treatments, which ranged from 45.66 to $52.06 \%$. However all applied fertilization treatments did not largely show appreciable differences in oil constituents. In addition, total carbohydrates $\%$ in the leaves of the plants was increased by using the treatment of full dose of NPK+biofertilizer. Also this treatment led to an increase in the macro elements $\mathrm{N}, \mathrm{P}$ and $\mathrm{K}$ in the plants, but biofertilizer only led to the lowest total carbohydrates $\%$ and the lowest $\mathrm{N}, \mathrm{P}$ and $\mathrm{K} \%$ in the leaves.
\end{abstract}

Keywords: savory, essential oil, oil constituents, carvacrol

Satureja hortensis L. is an annual, herbaceous aromatic and medicinal plant, belonging to the family Lamiaceae. It is known as summer 
savory, native to southern Europe and naturalized in parts of North America (Sefidkon et al., 2006). This plant is traditionally used as carminative, digestive, antispasmodic and antitussive in North America, Europe, Iran, Syria and Lebanon. The aerial parts of some Satureja plants have been widely used in foods as herbal tea and flavor component and in folk as well as traditional medicine, to treat various ailments, such as cramps, muscle pains, nausea, indigestion, diarrhea and infectious diseases (Gulluce et al., 2003). Literature review, on essential oil composition in Satureja species show to be rich in phenolic components such as carvacrol, $\gamma$-terpinene, thymol, $p$-cymene, $\beta$-caryophyllene, linalool and other terpenoids (Ravid and Putievsky, 1986). However, chemical composition and the amount of components have variation among the different Satureja species oils (Baher et al., 2002; Baser et al., 2004; Novak et al., 2006; Sefidkon et al., 2006 and Svoboda et al., 2006.). Some studies show that the essential oil and extract of Satureja species have demonstrated a variety of activities including antibacterial and antifungal properties and show a strong inhibition on a wide range of bacteria and fungi in human, food and plant pathogens (Deans et al., 1987; Inouye et al., 2001; Baydar et al., 2004; Boyraz and Özcan, 2006 and Klaric et al., 2007). Also, a number of studies have suggested that Satureja species have antioxidant properties (Dorman and Hiltunen, 2004 and Kulisic et al., 2005). In this context, the use of organic and chemical fertilizers can increase the yield of the essential oil and main components of medicinal plants (Baser et al., 2003; Arabaci and Bayram, 2004; Naghdibadi et al., 2004; Economakis, 2005 and Khalid et al., 2006), and it is also safe for human, animal and the environment. Eid and El-Ghawwas (2002) stated that plant height, number of branches/plant as well as fresh and dry weights of marjoram plants were significantly increased when plants were treated with microbein and nitrobein compared with untreated plants. In addition, Mahfouz (2003) found that the highest values of Majorana hortensis plant height, number of branches, fresh and dry weights of root were recorded for the treatment of biofertilizer plus full dose of $\mathrm{N}$ and $\mathrm{P}$ over the other treatments and control plants. Moreover, Abo El-Ala (2002) found that the combination between compost and biofertilizers increased plant fresh and dry weights in the fourth cut compared to the other treatments of marjoram plants. Mohsen (2002) and El-Sayed et al. (2002), who studied on sweet basil and Kandeel and Sharaf (2003), who studied on marjoram plants, stated that the highest oil percentage and oil yield/ha were obtained with plants inoculated pre-sowing with three bacterial partners (biological fertilizers) and half of the recommended field rate of the inorganic N, P and $\mathrm{K}$ fertilization. Shahram and Kourosh (2011) reported that medicinal plants are very important in modern civilization in order to obtain natural active substances, known as secondary metabolites. The production of natural substances by plants is affected by genotype and environmental conditions. Continuous usage of inorganic fertilizer affects soil structure. Hence, animal

Egyptian J. Desert Res., 65, No. 1, 101-123 (2015) 
and plant manures, compost and vermicompost can serve as alternative to mineral fertilizers for improving soil structure and microbial biomass. Biofertilizers such as plant growth promoting Rhizobacteria (PGPRs) and Mycorrhiza are microbial inoculants consisting of living cells of microorganism like bacteria and fungi, which may help in increasing crop productivity. Organic fertilizers in comparison to the chemical fertilizers have lower nutrient content with slow release, but they are as effective as chemical fertilizers over longer periods of use.

In this study, Satureja hortensis was cultivated as one of the most promising medicinal and aromatic plants in Egypt and the effects of chemical and/or biofertilization were evaluated on growth , productivity and essential oil composition,. This study can provide useful information for improvement of cultivated conditions of Satureja hortensis plants and investigation on the effects of fertilizer on yield and essential oil composition under the reclaimed land in Egypt conditions.

\section{MATERIALS AND METHODS}

This present study was carried out at Menia Governorate (Brotobat village-West Megaga Center, $200 \mathrm{~km}$ from Cairo), during the two successive seasons of 2013and 2014. The objective of this work was to study the effect of chemical fertilizers and biofertilizer on the vegetative growth and essential oil productivity of savory (Satureja hortensis) plants.

\section{Plant Material}

Seeds of savory (Satureja hortensis) were imported from Germany by Enza Zaden Co. An average weight of 1500 seeds was $1.0 \mathrm{~g}$.

\section{Sowing Dates}

Seeds of savory were sown on $15^{\text {th }}$ of February 2013 and 2014 (in the first and second seasons, respectively), at a nursery in seed flats (50x35 $\mathrm{cm}$ and depth of $15 \mathrm{~cm}$ with 208 cells) filled with a 1:1 (v/v) mixture of sand and peat moss. On $7^{\text {th }}$ of April during both seasons, the seedlings (with an average height of $15-20 \mathrm{~cm}$ and 4-6 leaves) were transplanted to the field at the Experimental Unit of Medicinal Plants EMAP Project (industrial development initiative aiming at upgrading Medicinal and Aromatic Plants (MAP) sector in Egypt) in Brotobat village-West Megaga Center. Planting was carried out in rows, $60 \mathrm{~cm}$ apart and the distance between plants was 35 $\mathrm{cm}$ (two plants/hill $=40000$ plants/feddan). Drip irrigation system was used with droppers of $4.0 \mathrm{~L} / \mathrm{h}$. The irrigation was given one hour daily. The analyses of soil and water are shown in tables (1 and 2). The chemical properties of soil in ppm (water: extract 1: $2.5 \mathrm{v} / \mathrm{v}$ ). 
Table (1). Mechanical and chemical properties of the soil.

\begin{tabular}{|c|c|c|c|c|c|c|c|c|c|c|}
\hline \multirow[t]{2}{*}{$\begin{array}{c}\text { Physical } \\
\text { properties }\end{array}$} & $\begin{array}{c}\text { Very } \\
\text { coarse } \\
\text { sand } \\
(\%)\end{array}$ & $\begin{array}{c}\text { Coarse } \\
\text { sand } \\
(\%)\end{array}$ & $\begin{array}{c}\text { Medium } \\
\text { sand } \\
(\%)\end{array}$ & $\begin{array}{c}\text { Fine } \\
\text { sand } \\
(\%)\end{array}$ & $\begin{array}{c}\text { Very fine } \\
\text { sand } \\
(\%)\end{array}$ & $\begin{array}{c}\text { Silt and } \\
\text { clay } \\
(\%)\end{array}$ & \multicolumn{4}{|c|}{ Soil texture } \\
\hline & 0.31 & 1.93 & 55.05 & 38.52 & 2.44 & 1.75 & & Sanc & oil & \\
\hline \multirow{3}{*}{$\begin{array}{l}\text { Chemical } \\
\text { properties }\end{array}$} & pH & E.C. & O.M. & \multicolumn{3}{|c|}{ Cations (meq/L) } & \multicolumn{4}{|c|}{ Anions (meq/L) } \\
\hline & 8.17 & 0.70 & 2.52 & $\mathrm{Ca}^{++}$ & $\mathrm{Mg}^{++}$ & $\mathbf{K}^{+}$ & $\mathrm{CO}_{3}^{-}$ & $\mathrm{HCO}_{3}^{-}$ & $\mathrm{Cl}^{-}$ & $\mathrm{SO}_{4}^{-}$ \\
\hline & & & & 4.08 & 0.82 & $\begin{array}{ll}50 & 0.25 \\
\end{array}$ & - & 1.91 & 3.00 & 4.74 \\
\hline
\end{tabular}

Table (2). Chemical analysis of irrigation water used.

\begin{tabular}{|c|c|c|c|c|c|c|c|c|c|}
\hline \multirow[t]{2}{*}{ EC } & \multirow[t]{2}{*}{$\mathbf{p H}$} & \multicolumn{4}{|c|}{ Soluble cations (ppm . ) } & \multicolumn{4}{|c|}{ Soluble anions (ppm) } \\
\hline & & $\mathrm{Ca}^{++}$ & $\mathrm{Mg}^{++}$ & $\mathrm{Na}^{+}$ & $\mathbf{K}^{+}$ & $\mathrm{CO}_{3}^{--}$ & $\mathrm{HCO}_{3}{ }^{-}$ & $\mathrm{SO}_{4}^{--}$ & $\mathrm{Cl}^{-}$ \\
\hline 0.717 & 7.65 & 90 & 16.20 & 75.00 & 5.00 & 19.90 & 154.33 & 95.00 & 95.50 \\
\hline
\end{tabular}

\section{Fertilizers Type}

\subsection{Chemical fertilizers}

The chemical fertilizers (full dose) of NPK were as follows:

- Nitrogen, at the rate of $200 \mathrm{~kg}$ per feddan as ammonium sulphate $(20.5 \%$ $\mathrm{N})$.

- Phosphorus, at the rate of $100 \mathrm{~kg}$ per feddan as calcium superphosphate $\left(\begin{array}{lll}15.5 \% & \mathrm{P}_{2} \mathrm{O}_{5}\end{array}\right)$.

- Potassium, at the rate of $50 \mathrm{~kg}$ per feddan as potassium sulphate (48\% $\mathrm{K}_{2} \mathrm{O}$ ).

Calcium superphosphate and organic fertilizer $\left(5 \mathrm{~m}^{3}\right.$ per feddan as compost manure) were added before planting in each season in only one dose. The compost manure was obtained from Sikem Company. The chemical characteristics of compost are shown in table (3). Common cultural practices throughout the experiment, including weed control were similarly done whenever needed. Nitrogen and potassium fertilizers were applied in three equal doses in the season. The first one was added one month after transplanting, the second and third doses were added one week after every cut. 
Table (3). The chemical properties of compost manure (CM) used for growing savory plants during 2013 and 2014 seasons.

\begin{tabular}{|c|c|c|c|c|c|c|c|c|c|}
\hline \multirow[t]{2}{*}{ pH } & \multirow[t]{2}{*}{$\begin{array}{c}\text { E.C } \\
\text { (mmhos) }\end{array}$} & \multicolumn{4}{|c|}{$\begin{array}{l}\text { Soluble cations } \\
(\mathrm{meq} / \mathrm{L})\end{array}$} & \multicolumn{4}{|c|}{$\begin{array}{c}\text { Soluble anions } \\
(\mathrm{meq} / \mathrm{L})\end{array}$} \\
\hline & & $\mathbf{C a}^{++}$ & $\mathbf{M g}^{++}$ & $\mathrm{Na}^{+}$ & $\mathbf{K}^{+}$ & $\mathrm{CO}_{3}{ }^{-}$ & $\mathrm{HCO}_{3}{ }^{-}$ & $\mathrm{Cl}^{-}$ & $\mathrm{SO}_{4}{ }^{-1}$ \\
\hline 8.10 & 3.10 & 15.00 & 45.00 & 90.00 & 30.00 & - & 45.00 & 10.00 & 140.50 \\
\hline \multicolumn{2}{|c|}{ Humidity\% } & Ash\% & O.M.\% & \multicolumn{2}{|c|}{ N\% } & \multicolumn{2}{|c|}{ P\% } & \multicolumn{2}{|c|}{ K\% } \\
\hline \multicolumn{2}{|c|}{25} & 9 & 65 & \multicolumn{2}{|c|}{2} & \multicolumn{2}{|c|}{1.5} & \multicolumn{2}{|c|}{1} \\
\hline
\end{tabular}

\subsection{Biofertilizers}

Biofertilizers were added as a mixture of 5 strains of bacteria namely: Azotobacter chroococcum, Azospirillum lipoferum, Bacillus polymixa, Bacillus megatherium and Pseudomonas fluorescence $\left(1 \mathrm{X} 10^{8} /\right.$ c.f.u). They were obtained from Desert Research Center, ElMatareya, Cairo, Egypt. The biofertilizer was added as a soil drench four times per season, i.e. one addition per month.

The treatments were conducted as follows:

1. Application of full dose of NPK.

2. Application of $1 / 4$ NPK dose+biofertilizer

3. Application of $1 / 2$ NPK dose+biofertilizer

4. Application of $3 / 4$ NPK dose+biofertilizer

5. Application of full dose of NPK+biofertilize.

6. Application of biofertilizer only.

\section{Harvesting}

The plants in the both seasons were harvested 3 times per season, i.e. on $10^{\text {th }}$ of June, $10^{\text {th }}$ of August and $25^{\text {th }}$ of September for the first season and $5^{\text {th }}$ of June, $15^{\text {th }}$ of August and $30^{\text {th }}$ of September for the second one by cutting the vegetative parts of plants $10 \mathrm{~cm}$ above the soil surface leaving 2 small branches with some leaves for regrowth.

The following data were recorded at harvesting time of each cut:

- Plant height $(\mathrm{cm})$.

- Fresh and dry weights of herb (g/plant and $\mathrm{kg} /$ feddan) - Leaves dry weight $(\mathrm{g} /$ plant and $\mathrm{kg} / \mathrm{feddan})$. The herb was dried at $70^{\circ} \mathrm{C}$ until a constant weight was obtained, and then the herb dry weight was recorded.

\section{Statistical analysis}

The experimental layout was a complete randomized design with three replicates, each replicate contained 10 plants. Data from all experiments were subjected to analysis of variance using Costat Statistical Software (1986). Means of all data were compared by L.S.D. method according to Snedecor and Cochran (1968). 


\section{Chemical Analysis \\ 6.1. Determination of essential oil percentage}

The essential oil percentage was determined in both seasons from air dried herb where the three cuts were carried out during the flowering stages according to British Pharmacopoeia (1963).

\subsection{GC/ Mass analysis of volatile oil}

The essential oil was analyzed on a VG analytical 70-250S sector field mass spectrometer, $70 \mathrm{eV}$, using a SPsil5, $25 \mathrm{mx} 30 \mathrm{~m}, 0.25 \mu \mathrm{m}$ coating thickness, fused silica capillary column, injector $222^{\circ} \mathrm{C}$, detector $240^{\circ} \mathrm{C}$, linear temperature $80^{\circ}-270^{\circ} \mathrm{C}$ at $10^{\circ} \mathrm{C} / \mathrm{min}$. Diluted samples $(1 / 100, \mathrm{v} / \mathrm{v}$, in $n$-pentane) of $1 \mu \mathrm{l}$ were injected, at $250{ }^{\circ} \mathrm{C}$, manually and in the splitless mode flame ionization detection (FID), using the HP Chemstation software on a HP $5980 \mathrm{GC}$ with the same type column as used for GC/MS and same temperature program.

Identification was made by library searches combining MS and retention data of authentic compounds by comparison of their GC retention indices (RI) with those of the literature or with those of standards available in our laboratories (Adams, 2007).

\subsection{Determination of nitrogen, phosphorus and potassium percentages} in the herb

The chemical analysis was carried out on the dry leaves samples representing the three cuts obtained from the different treatments. The dry leaves were ground to a fine powder for the determination of $\mathrm{N}, \mathrm{P}$ and $\mathrm{K}$ nutrients. N, P and $\mathrm{K}$ content were determined in the acid digested solution, which was prepared according to Hach et al. (1985).

Nitrogen content was determined by modified micro-kjeldahle method as described by A.O.A.C. (1970). Phosphorus was determined colormetrically using the method described by Murphy and Riley (1962). Potassium was estimated using flame photometery method according to Cottenie et al. (1982).

\subsection{Determination of total carbohydrates}

Total carbohydrates percentage in the dried leaves was determined according to Herbert et al. (1971).

\section{RESULTS AND DISCUSSION}

\section{Vegetative Growth}

Data presented in table (4) clearly show that the lowest mean values of plant height $(\mathrm{cm})$ of Satureja hortensis was recorded during the three cuts when biofertilizer was applied alone, also $1 / 4$ NPK dose+biofertilizer resulted in less values for plant height than full dose of chemical fertilizer. However, $1 / 2$ NPK dose+biofertilizer and full dose of NPK+biofertilizer appeared to satisfy in enhancing plant height comparing to other treatments. Concerning fresh and dry weight of plant, data presented in tables (5 and 6) indicate that 
application of either biofertilizer alone or $1 / 4$ NPK dose or $1 / 2$ NPK+biofertilizer significantly heaviest decreased fresh and dry weight/plant comparing to full dose of NPK as chemical fertilizer, while the significantly fresh and dry weight/plant resulted from the treatments of $3 / 4$ NPK dose or full NPK dose+biofertilizer comparing to using NPK chemical fertilizer alone. Similar trend of fresh and dry weight was also clear for leaves dry weight/plant as presented in table (7).

Table (4). Effect of fertilization treatments on plant height $(\mathrm{cm})$ of savory for 3 cuts during two successive seasons (2013 and 2014).

\begin{tabular}{|c|c|c|c|c|}
\hline \multicolumn{5}{|c|}{$1^{\text {st }}$ Season } \\
\hline Fertilization treatments & $\mathbf{1}^{\text {st }}$ & $2^{\text {nd }}$ cut & $3^{\text {rd }}$ & Mean \\
\hline Full dose of NPK & 40.0 & 35.00 & 30.00 & 35.00 \\
\hline 1/4 NPK dose+biofertilizer & 30.0 & 31.00 & 26.00 & 29.00 \\
\hline $1 / 2$ NPK dose+biofertilizer & 35.0 & 34.00 & 32.00 & 33.67 \\
\hline 3/4 NPK dose+biofertilizer & 33.0 & 33.00 & 32.00 & 32.67 \\
\hline Full dose of NPK+biofertilizer & 34.0 & 36.00 & 32.00 & 34.00 \\
\hline Biofertilizer only & 22.0 & 23.00 & 22.00 & 22.33 \\
\hline Mean & 32.3 & 32.00 & 29.00 & \\
\hline L.S.D. at 0.05 & 1.91 & 1.73 & 1.81 & \\
\hline \multicolumn{5}{|c|}{$2^{\text {nd }}$ Season } \\
\hline Full dose of NPK & 43.00 & 37.00 & 33.00 & 37.67 \\
\hline 1/4 NPK dose+biofertilizer & 32.00 & 30.00 & 28.00 & 30.00 \\
\hline $1 / 2$ NPK dose+biofertilizer & 37.00 & 35.00 & 33.00 & 35.00 \\
\hline $3 / 4$ NPK dose+biofertilizer & 31.00 & 30.00 & 31.00 & 30.67 \\
\hline Full dose of NPK+biofertilizer & 38.00 & 34.00 & 31.00 & 34.33 \\
\hline Biofertilizer only & 25.00 & 22.00 & 20.00 & 22.33 \\
\hline Mean & 34.33 & 31.33 & 29.33 & \\
\hline L.S.D. at 0.05 & 1.89 & 1.75 & 1.85 & \\
\hline
\end{tabular}

The stimulatory effect of the treatment of full dose of NPK on vegetative growth may be due to the role of NPK fertilization on the plant physiological processes, and this dose is enough for giving significantly healthy vegetative growth. With regard to the effect of the treatment of full dose of NPK+biofertilizer, may be due to that the inoculation with symbiotic nitrogen fixers increases soil available nitrogen and consequently, increases the formation of metabolites, which encouraged the plant vegetative growth. Also, $\mathrm{N}_{2}$ fixers synthesize vitamins, amino acids, auxins and gibberellins, which stimulate plant growth (Sperenat, 1990 and El-Merich et al., 1997). Furthermore, the role of phosphate dissolving bacteria, which possess the ability to bring insoluble phosphorus in the soil into soluble forms (Gaur and Ostwal, 1972). These results were coincided with those obtained by Abo ElAla (2002) on Ocimum basilicum and Majorana hortensis, Osman (2000) on coriander plants, Rai et al. (2002) on fennel and Kandeel and Sharaf (2003) on marjoran. 
Table (5). Effect of fertilization treatments on fresh weight of savory herb (g/plant ) for 3 cuts during two successive seasons (2013 and 2014).

\begin{tabular}{lcccc}
\hline & $\mathbf{1}^{\text {st }}$ Season & & & \\
\hline Fertilization treatments & $\mathbf{1}^{\text {st }}$ cut & $\mathbf{2}^{\text {nd }}$ cut & $\mathbf{3}^{\text {rd }}$ cut & Mean \\
\hline Full dose of NPK & 175 & 190 & 165.00 & 182.50 \\
1/4 NPK dose+biofertilizer & 150 & 160 & 125 & 145.00 \\
1/2 NPK dose+biofertilizer & 165 & 185 & 155 & 168.33 \\
3/4 NPK dose+biofertilizer & 180 & 235 & 175 & 196.67 \\
Full dose of NPK+biofertilizer & 190 & 225 & 180 & 198.33 \\
Biofertilizer only & 100 & 110 & 95 & 101.67 \\
Mean & 111.67 & 132.58 & 99.33 & \\
L.S.D. at 0.05 & 7.25 & 7.85 & 8.20 & \\
\hline & $\mathbf{2}^{\text {nd }}$ Season & & & \\
\hline Full dose of NPK & 180 & 200 & 160.00 & 190.00 \\
1/4 NPK dose+biofertilizer & 155 & 170 & 120 & 148.33 \\
1/2 NPK dose+biofertilizer & 160 & 190 & 145 & 165.00 \\
3/4 NPK dose+biofertilizer & 190 & 240 & 170 & 200.00 \\
Full dose of NPK+biofertilizer & 200 & 225 & 175 & 200.00 \\
Biofertilizer only & 90 & 105 & 90 & 95.00 \\
Mean & 162.50 & 188.33 & 140.00 & \\
L.S.D. at 0.05 & 7.23 & 8.11 & 8.15 & \\
\hline
\end{tabular}

Table (6). Effect of fertilization treatments on dry weight of savory herb (g/plant) for 3 cuts during two successive seasons (2013 and 2014).

\begin{tabular}{|c|c|c|c|c|}
\hline \multicolumn{5}{|c|}{$1^{\text {st }}$ Season } \\
\hline Fertilization treatments & $1^{\text {st }}$ cut & $2^{\text {nd }}$ cut & $3^{\text {rd }}$ cut & Mean \\
\hline Full dose of NPK & 35.00 & 37.00 & 27.00 & 36.00 \\
\hline 1/4 NPK dose+biofertilizer & 28.00 & 40.00 & 23.00 & 30.33 \\
\hline $1 / 2$ NPK dose+biofertilizer & 40.00 & 43.00 & 26.00 & 36.33 \\
\hline $3 / 4$ NPK dose+biofertilizer & 42.00 & 48.00 & 44.00 & 44.67 \\
\hline Full dose of NPK+biofertilizer & 50.00 & 53.00 & 47.00 & 50.00 \\
\hline Biofertilizer only & 19.00 & 15.00 & 13.00 & 15.67 \\
\hline Mean & 35.67 & 39.33 & 30.60 & 35.20 \\
\hline L.S.D. at 0.05 & 3.25 & 3.85 & 3.20 & \\
\hline \multicolumn{5}{|c|}{$2^{\text {nd }}$ Season } \\
\hline Full dose of NPK & 36.00 & 39.00 & 23.00 & 37.50 \\
\hline 1/4 NPK dose+biofertilizer & 30.00 & 41.00 & 21.00 & 30.67 \\
\hline $1 / 2$ NPK dose+biofertilizer & 41.00 & 45.00 & 23.00 & 36.33 \\
\hline $3 / 4$ NPK dose+biofertilizer & 45.00 & 50.00 & 42.00 & 45.67 \\
\hline Full dose of NPK+biofertilizer & 53.00 & 56.00 & 45.00 & 51.33 \\
\hline Biofertilizer only & 22.00 & 17.00 & 14.00 & 17.67 \\
\hline Mean & 37.83 & 41.33 & 29.00 & \\
\hline L.S.D. at 0.05 & 3.93 & 3.50 & 3.15 & \\
\hline
\end{tabular}


Table (7). Effect of fertilization treatments on dry leaves /plant (gm) of savory for 3 cuts during two successive seasons (2013 and 2014).

\begin{tabular}{|c|c|c|c|c|}
\hline \multicolumn{5}{|c|}{$1^{\text {st }}$ Season } \\
\hline Fertilization treatments & $1^{\text {st }}$ cut & $2^{\text {nd }}$ cut & $3^{\text {rd }}$ cut & Mean \\
\hline Full dose of NPK & 17.50 & 19.6 & 15.30 & 18.55 \\
\hline 1/4 NPK dose+biofertilizer & 15.84 & 16.45 & 12.7 & 15.00 \\
\hline $1 / 2$ NPK dose+biofertilizer & 17.11 & 18.22 & 14.23 & 16.52 \\
\hline $3 / 4$ NPK dose+biofertilizer & 19.25 & 20.67 & 19.3 & 19.74 \\
\hline Full dose of NPK+biofertilizer & 21.28 & 23.34 & 20.44 & 21.69 \\
\hline Biofertilizer only & 13.36 & 14.12 & 11.87 & 11.04 \\
\hline Mean & 17.14 & 18.50 & 15.05 & \\
\hline L.S.D. at 0.05 & 1.90 & 2.11 & 2.05 & \\
\hline \multicolumn{5}{|c|}{$2^{\text {nd }}$ Season } \\
\hline Full dose of NPK & 18.40 & 20.7 & 16.40 & 19.55 \\
\hline $1 / 4$ NPK dose+biofertilizer & 16.33 & 17.66 & 13.16 & 15.72 \\
\hline $1 / 2$ NPK dose+biofertilizer & 17.88 & 19.44 & 14.95 & 17.42 \\
\hline $3 / 4$ NPK dose+biofertilizer & 19.87 & 21.87 & 19.79 & 20.51 \\
\hline Full dose of NPK+biofertilizer & 21.88 & 24.67 & 21.35 & 22.63 \\
\hline Biofertilizer only & 13.88 & 14.69 & 10.56 & 13.04 \\
\hline Mean & 18.04 & 19.84 & 15.96 & \\
\hline L.S.D. at 0.05 & 1.55 & 1.98 & 1.59 & \\
\hline
\end{tabular}

\section{Essential Oil Percentage and Yield}

Data presented in table (8) indicate that application of biofertilizer alone was the promising treatment for enhancing oil percentage accumulation comparing to the other fertilizer treatments, followed by the treatment $1 / 4$ NPK dose+biofertilizer in the $1^{\text {st }}$ and $2^{\text {nd }}$ cuts, during both seasons, comparing to other treatments. On the other side, application of biofertilizer alone resulted in the lowest value of oil yield/plant (Table 9), also $1 / 4$ NPK dose+biofertilizer resulted in less significant oil yield/plant, while full dose of NPK+biofertilizer gave the maximum mean values of essential oil yield (ml/plant) in the $1^{\text {st }}$ and $2^{\text {nd }}$ cuts, during both seasons, whereas, $1 / 2$ NPK dose+biofertilizer treatment was the effective treatment for enhancing oil yield/plant in the $1^{\text {st }}$ and $2^{\text {nd }}$ cuts, during both seasons.

\section{Essential Oil Constituents}

Data presented in table (10) indicate that among 17 detected compounds in the essential oil, carvacrol was the highest constituent, followed by P-cymene, $\alpha$-terpinene, $\alpha$-phellandrene, $\beta$ - pinene and sabinene hydrate, descendingly. On the other hand, the least value was belonging to $\alpha$-bisabolene and camphene compounds. As for the effect of applied treatments on oil constituents, it is clear that application of biofertilizer alone decreased carvacrol percentage, since it was $45.66 \%$, comparing to other applied treatments, which ranged from 45.66 and 52.06\%. However all applied fertilization treatments did not largely show appreciable differences in oil constituents. 
The results may be attributed to antagonism to phosphate solubilization. These bacteria may improve plant $\mathrm{P}$ acquisition by solubilizing organic and inorganic phosphate sources through phosphatase synthesis or by lowering the $\mathrm{pH}$ of the soil (Dart, 1986; Goldstein, 1986 and Sharafzadeh, 2011). According Sharafzadeh (2011), nutrients are able to change growth and total phenolic content of garden thyme. Brown (1974) revealed that Azotobacter paspali can release IAA in the medium and Reda et al. (2005) reported that growth regulators increase total phenolic content in thyme. Nutrient availability affects the production of polyphenolic compounds in three cultivars (Dark Opal, Genovese, and Sweet Thai) of basil (Nguyen and Niemeyer, 2008). Nitrogen and phosphorus play important role in essential oil biosynthesis. Besides, production of pyruvate, these elements are present in ATP, NADP and CoA structure on which terpenoid biosynthesis depend of such coenzymes (Sell, 2003 and Kapoor et al., 2004).

Table (8). Effect of fertilization treatments on essential oil percentage in dry herb of savory (Satureja hortensis) for 3 cuts during two successive seasons (20132014).

\begin{tabular}{lcccc}
\hline & $\mathbf{1}^{\text {st }}$ Season & & & \\
\hline Fertilization treatments & $\mathbf{1}^{\text {st }}$ cut & $\mathbf{2}^{\text {nd }}$ cut & $\mathbf{3}^{\text {rd }}$ cut & Mean \\
\hline Full dose of NPK & 1.88 & 2.20 & 1.53 & 1.87 \\
1/4 NPK dose+biofertilizer & 2.32 & 2.55 & 1.81 & 2.23 \\
1/2 PK dose+biofertilizer & 2.25 & 2.42 & 1.70 & 2.12 \\
3/4 NPK dose+biofertilizer & 2.15 & 2.36 & 1.64 & 2.05 \\
Full dose of NPK+biofertilizer & 2.10 & 2.22 & 1.66 & 1.99 \\
Biofertilizer only & 2.42 & 2.77 & 2.18 & 2.46 \\
Mean & 2.19 & 2.42 & 1.75 & \\
L.S.D. at 0.05 & 0.11 & 0.05 & 0.04 & \\
\hline & $\mathbf{2}^{\text {nd }}$ Season & & & \\
\hline Full dose of NPK & 1.91 & 2.31 & 1.57 & 1.93 \\
1/4 NPK dose+biofertilizer & 2.43 & 2.60 & 1.87 & 2.30 \\
1/2 NPK dose+biofertilizer & 2.36 & 2.45 & 1.75 & 2.19 \\
3/4 NPK dose+biofertilizer & 2.20 & 2.41 & 1.69 & 2.10 \\
Full dose of NPK+biofertilizer & 2.16 & 2.29 & 1.71 & 2.05 \\
Biofertilizer only & 2.48 & 2.81 & 2.23 & 2.51 \\
Mean & 2.26 & 2.48 & 1.80 & \\
L.S.D. at 0.05 & 0.08 & 0.05 & 0.03 & \\
\hline
\end{tabular}


Table (9). Effect of fertilization treatments on oil yield (ml/plant) of savory for 3 cuts during two successiveseasons (2013 and 2014).

\begin{tabular}{lcccc}
\hline & $\mathbf{1}^{\text {st }}$ Season & & & \\
\hline Fertilization treatments & $\mathbf{1}^{\text {st }}$ cut & $\mathbf{2}^{\text {nd }}$ cut & $\mathbf{3}^{\text {rd }}$ cut & Mean \\
\hline Full dose of NPK & 0.35 & 0.37 & 0.27 & 0.33 \\
1/4 NPK dose+biofertilizer & 0.28 & 0.40 & 0.23 & 0.30 \\
1/2 NPK dose+biofertilizer & 0.40 & 0.43 & 0.26 & 0.36 \\
3/4 NPK dose+biofertilizer & 0.42 & 0.48 & 0.44 & 0.45 \\
Full dose of NPK+biofertilizer & 0.50 & 0.53 & 0.47 & 0.50 \\
Biofertilizer only & 0.19 & 0.15 & 0.13 & 0.16 \\
Mean & 0.36 & 0.39 & 0.30 & \\
L.S.D. at 0.05 & 0.04 & 0.03 & 0.03 & \\
\hline & $\mathbf{2}^{\text {nd }}$ Season & & & \\
\hline Full dose of NPK & 0.36 & 0.39 & 0.23 & 0.33 \\
1/4 NPK dose+biofertilizer & 0.30 & 0.41 & 0.21 & 0.31 \\
1/2 NPK dose+biofertilizer & 0.41 & 0.45 & 0.23 & 0.36 \\
3/4 NPK dose+biofertilizer & 0.45 & 0.50 & 0.42 & 0.46 \\
Full dose of NPK+biofertilizer & 0.53 & 0.56 & 0.45 & 0.51 \\
Biofertilizer only & 0.22 & 0.17 & 0.14 & 0.18 \\
Mean & 0.38 & 0.41 & 0.28 & \\
L.S.D. at 0.05 & 0.04 & 0.03 & 0.02 & \\
\hline
\end{tabular}

Table (10). Chemical composition of essential oils in savory in response to fertilization treatments.

\begin{tabular}{|c|c|c|c|c|c|c|c|}
\hline \multirow{2}{*}{\multicolumn{2}{|c|}{ Compound }} & \multirow{2}{*}{\multicolumn{6}{|c|}{ Content $\mu \mathrm{g} / 1 \mu \mathrm{L}$ in six accessions }} \\
\hline & & & & & & & \\
\hline 1 & $\alpha$-Thujene & $\begin{array}{c}\begin{array}{c}\text { Full } \\
\text { dose of } \\
\text { NPK }\end{array} \\
1.21\end{array}$ & $\begin{array}{c}\begin{array}{c}\text { 1/4 NPK dose } \\
+ \\
\text { biofertilizer }\end{array} \\
1.23\end{array}$ & $\begin{array}{c}1 / 2 \text { PK dose }+ \\
\text { biofertilizer } \\
1.25\end{array}$ & $\begin{array}{c}\begin{array}{c}\text { 3/4 NPK dose } \\
+ \\
\text { biofertilizer }\end{array} \\
1.28\end{array}$ & $\begin{array}{c}\begin{array}{c}\text { Full dose of } \\
\text { NPK } \\
+ \text { biofertilizer }\end{array} \\
1.33\end{array}$ & $\begin{array}{c}\begin{array}{c}\text { Biofertilizer } \\
\text { only }\end{array} \\
1.15\end{array}$ \\
\hline 2 & $\alpha$ - Pinene & 1.11 & 1.14 & 1.13 & 1.17 & 1.22 & 0.85 \\
\hline 3 & Camphene & 0.08 & 0.10 & 0.11 & 0.16 & 0.21 & 0.08 \\
\hline 4 & $\beta$ - Pinene & 1.82 & 1.62 & 1.34 & 1.39 & 1.42 & 1.88 \\
\hline 5 & Myrcene & 0.57 & 0.52 & 0.87 & 0.98 & 1.03 & 0.34 \\
\hline 6 & $\alpha$-Phellandrene & 2.91 & 2.97 & 3.17 & 3.21 & 3.18 & 3.10 \\
\hline 7 & $\alpha$-Terpinene & 4.11 & 3.05 & 3.11 & 2.89 & 3.06 & 3.11 \\
\hline 8 & P-Cymene & 37.22 & 32.13 & 34.11 & 34.65 & 34.91 & 32.22 \\
\hline 9 & $\delta$-Terpinene & 0.55 & 0.51 & 0.35 & 0.31 & 0.38 & 0.51 \\
\hline 10 & Sabinene hydrate & 1.30 & 2.33 & 2.64 & 2.66 & 2.81 & 1.30 \\
\hline 11 & Terpinolene & 0.14 & 0.16 & 0.16 & 0.19 & 0.17 & 0.14 \\
\hline 12 & Terpinene-4-OL & 0.25 & 0.35 & 0.35 & 0.38 & 0.41 & 0.15 \\
\hline 13 & Carvacrol & 45.66 & 50.85 & 48.75 & 47.93 & 47.12 & 52.06 \\
\hline 14 & $\beta$-caryophyllene & 0.53 & 0.59 & 0.42 & 0.46 & 0.49 & 0.53 \\
\hline 15 & bicyclogermacrene & 0.14 & 0.18 & 0.17 & 0.16 & 0.18 & 0.10 \\
\hline 16 & $\beta$-bisabolene & 0.51 & 0.56 & 0.36 & 0.33 & 0.35 & 0.55 \\
\hline \multirow[t]{2}{*}{17} & $\alpha$-bisabolene & 0.05 & 0.06 & 0.11 & 0.13 & 0.12 & 0.04 \\
\hline & Total & 98.16 & 98.35 & 98.40 & 98.28 & 98.39 & 98.11 \\
\hline
\end{tabular}




\section{Nitrogen, Phosphorus and Potassium Percentages in the Leaves}

Data presented in tables (11, 12 and 13) indicate that NPK percentages recorded the least values with biofertilizer application alone, also $1 / 4$ NPK dose+biofertilizer significantly decreased NPK percentages comparing to chemical NPK fertilizer alone or combined with biofertilizer. On the other side, application of full NPK dose+biofertilizer followed by $3 / 4$ NPK dose+biofertilizer showed its superiority for increasing NPK percentages in the leaves.

Data presented in table (14) show that the least total carbohydrates percentage was recorded when biofertilizer was applied alone, that were analogous to application of $1 / 4$ NPK dose+biofertilizer, while the highest total carbohydrates \% was obtained from the treatment of full dose of NPK+biofertilizer, followed descendingly by using the treatment of $3 / 4$ NPK dose+biofertilizer, while $1 / 2$ NPK dose resulted in similar values of total carbohydrates obtained by NPK chemical fertilizer alone.

Table (11). Effect of fertilization treatments on nitrogen $(\mathrm{N}) \%$ in the leaves of savory for 3 cuts in two seasons (2013 and 2014).

\begin{tabular}{lcccc}
\hline & $\mathbf{1}^{\text {st }}$ Season & & & \\
\hline Fertilization treatments & $\mathbf{1}^{\text {st }}$ cut & $\mathbf{2}^{\text {nd }}$ cut & $\mathbf{3}^{\text {rd }}$ cut & Mean \\
\hline Full dose of NPK & 1.35 & 1.44 & 1.42 & 1.40 \\
1/4 NPK dose+biofertilizer & 1.24 & 1.26 & 1.22 & 1.24 \\
1/2 PK dose+biofertilizer & 1.34 & 1.36 & 1.35 & 1.35 \\
3/4 NPK dose+biofertilizer & 1.43 & 1.55 & 1.45 & 1.48 \\
Full dose of NPK+biofertilizer & 1.61 & 1.72 & 1.56 & 1.63 \\
Biofertilizer only & 1.18 & 1.15 & 1.14 & 1.16 \\
Mean & 1.36 & 1.41 & 1.36 & \\
\hline & $\mathbf{2}^{\text {nd }}$ Season & & & \\
\hline Full dose of NPK & 1.37 & 1.48 & 1.46 & 1.44 \\
1/4 NPK dose+biofertilizer & 1.28 & 1.31 & 1.26 & 1.28 \\
1/2 NPK dose+biofertilizer & 1.38 & 1.41 & 1.39 & 1.39 \\
3/4 NPK dose+biofertilizer & 1.44 & 1.58 & 1.49 & 1.50 \\
Full dose of NPK+biofertilizer & 1.63 & 1.74 & 1.59 & 1.65 \\
Biofertilizer only & 1.21 & 1.18 & 1.16 & 1.18 \\
Mean & 1.39 & 1.45 & 1.39 & \\
\hline
\end{tabular}


Table (12). Effect of fertilization treatments on phosphorus (P) \% in the leaves of savory for 3 cuts in two seasons (2013 and 2014).

\begin{tabular}{lcccc}
\hline & $\mathbf{1}^{\text {st }}$ Season & & & \\
\hline Fertilization treatments & $\mathbf{1}^{\text {st }}$ cut & $\mathbf{2}^{\text {nd }}$ cut & $\mathbf{3}^{\text {rd }}$ cut & Mean \\
\hline Full dose of NPK & 0.32 & 0.32 & 0.31 & 0.32 \\
1/4 NPK dose+biofertilizer & 0.23 & 0.27 & 0.23 & 0.24 \\
1/2 NPK dose+biofertilizer & 0.34 & 0.32 & 0.32 & 0.33 \\
3/4 NPK dose+biofertilizer & 0.33 & 0.35 & 0.35 & 0.34 \\
Full dose of NPK+biofertilizer & 0.35 & 0.35 & 0.34 & 0.35 \\
Biofertilizer only & 0.22 & 0.24 & 0.24 & 0.23 \\
Mean & 0.30 & 0.31 & 0.30 & \\
\hline & $\mathbf{2}^{\text {nd }}$ Season & & & \\
\hline Full dose of NPK & 0.33 & 0.32 & 0.3 & 0.32 \\
1/4 NPK dose+biofertilizer & 0.24 & 0.26 & 0.22 & 0.24 \\
1/2 NPK dose+biofertilizer & 0.35 & 0.31 & 0.31 & 0.32 \\
3/4 NPK dose+biofertilizer & 0.34 & 0.34 & 0.34 & 0.34 \\
Full dose of NPK+biofertilizer & 0.36 & 0.34 & 0.33 & 0.34 \\
Biofertilizer only & 0.23 & 0.23 & 0.23 & 0.23 \\
Mean & 0.31 & 0.30 & 0.29 & \\
\hline
\end{tabular}

Table (13). Effect of fertilization treatments on potassium (K) \% in the leaves of savory for three cuts in two seasons (2013 and 2014).

\begin{tabular}{lcccc}
\hline & $\mathbf{1}^{\text {st }}$ Season & & & \\
\hline Fertilization treatments & $\mathbf{1}^{\text {st }}$ cut & $\mathbf{2}^{\text {nd }}$ cut & $\mathbf{3}^{\text {rd }}$ cut & Mean \\
\hline Full dose of NPK & 1.19 & 1.31 & 1.22 & 1.24 \\
1/4 NPK dose+biofertilizer & 1.11 & 1.15 & 1.13 & 1.13 \\
1/2 NPK dose+biofertilizer & 1.19 & 1.22 & 1.07 & 1.16 \\
3/4 NPK dose+biofertilizer & 1.28 & 1.33 & 1.24 & 1.28 \\
Full dose of NPK+biofertilizer & 1.37 & 1.44 & 1.41 & 1.41 \\
Biofertilizer only & 1.06 & 1.11 & 1.09 & 1.09 \\
Mean & 1.20 & 1.26 & 1.19 & \\
\hline & $\mathbf{2}^{\text {nd }}$ Season & & & \\
\hline Full dose of NPK & 1.21 & 1.34 & 1.23 & 1.26 \\
1/4 NPK dose+biofertilizer & 1.14 & 1.17 & 1.12 & 1.14 \\
1/2 NPK dose+biofertilizer & 1.22 & 1.24 & 1.11 & 1.19 \\
3/4 NPK dose+biofertilizer & 1.31 & 1.36 & 1.27 & 1.31 \\
Full dose of NPK+biofertilizer & 1.36 & 1.42 & 1.39 & 1.39 \\
Biofertilizer only & 1.07 & 1.13 & 1.07 & 1.09 \\
Mean & 1.22 & 1.28 & 1.20 & \\
\hline
\end{tabular}


Table (14). Effect of fertilization treatments on total carbohydrates $\%$ in the leaves of savory for 3 cuts in two seasons (2013 and 2014).

\begin{tabular}{|c|c|c|c|c|}
\hline \multicolumn{5}{|c|}{$\mathbf{1}^{\text {st }}$ Season } \\
\hline Fertilization treatments & $1^{\text {st }}$ cut & $2^{\text {nd }}$ cut & $3^{\text {rd }}$ cut & Mean \\
\hline Full dose of NPK & 19.65 & 20.34 & 21.54 & 22.51 \\
\hline 1/4 NPK dose+biofertilizer & 14.22 & 15.12 & 15.15 & 14.50 \\
\hline $1 / 2 \mathrm{PK}$ dose+biofertilizer & 19.23 & 20.3 & 21.3 & 21.00 \\
\hline 3/4 NPK dose+biofertilizer & 20.11 & 21.5 & 21.1 & 22.40 \\
\hline Full dose of NPK+biofertilizer & 22.13 & 22.75 & 21.58 & 23.39 \\
\hline Biofertilizer only & 12.1 & 14.4 & 11.35 & 14.62 \\
\hline Mean & 17.91 & 19.07 & 18.67 & \\
\hline \multicolumn{5}{|c|}{$2^{\text {nd }}$ Season } \\
\hline Full dose of NPK & 19.14 & 20.68 & 21.21 & 20.34 \\
\hline 1/4 NPK dose+biofertilizer & 14.33 & 15.63 & 15.34 & 15.10 \\
\hline $1 / 2$ NPK dose+biofertilizer & 19.44 & 20.87 & 21.54 & 20.62 \\
\hline $3 / 4$ NPK dose+biofertilizer & 20.42 & 21.88 & 21.65 & 21.32 \\
\hline Full dose of NPK+biofertilizer & 22.57 & 23.25 & 21.17 & 22.33 \\
\hline Biofertilizer only & 13.41 & 14.66 & 11.55 & 13.21 \\
\hline Mean & 18.22 & 19.50 & 18.74 & \\
\hline
\end{tabular}

The obtained results of the herein work indicated that in sandy soil, application of a biofertilizer as mixture of 5 strains of bacteria, namely Azotobacter chroococcum, Azospirillum lipoferum, Bacillus polymixa, Bacillus megatherium and Pseudomonas fluorescence was not effective on obtaining high herb or oil constituents yield but showed its superiority for increasing the oil percentages in the plants of Satureja hortensis; Whereas, comparing to both chemical fertilization of $1 / 2$ NPK dose + biofertilizer, also $1 / 4$ NPK dose + biofertilizer were not promising, but application of each of $3 / 4$ and or full dose of NPK + biofertilizer were analogues to application of NPK alone as chemical fertilizer.

To interperete and evaluate the influence of nitrogen, phosphorus and potassium on improving vegetative growth characters and essential oil productivity of savory plants, it was important to refer to the physiological roles of nitrogen, phosphorus and potassium in plant growth and development (Cooke, 1982). Nitrogen is essential for plant growth and development as a constituent of many amino acids, enzymes and energy transfer materials; such as chlorophyll, ADP and ATP. Growing plants must have nitrogen to form new cells and the rate of growth then becomes very nearly proportional to the rate at which nitrogen is supplied. So, a severe shortage of nitrogen will halt the processes of growth and reproduction (Bidwell, 1974; Thompsond and Troeh, 1975 and Said Al Ahl et al., 2009).

Phosphorus is essential for cell division and for development of meristimmatic tissues and it is very important for carbohydrate transformation due to multitude of phosphorylation reaction and to energy rich phosphate bonds (Lambers et al., 2000). Cells can not divide unless there 
is adequate phosphorus to form the extra nucleus. Phosphorus compounds are also essential for photosynthesis, the inter conversion of carbohydrates and related glycolysis, amino acid metabolism, fat metabolism and biological oxidation. Lack of phosphorus, therefore hampers metabolic processes, such as the conversion of sugars into starch and cellulose (Devlin, 1972).

Potassium is important for growth and elongation probably due to its function as an osmoticum and may react synergistically with IAA. Moreover, it promotes $\mathrm{CO}_{2}$ assimilation and translocation of carbohydrates from the leaves to storage tissues (Mengel and Kirkby, 1987).

The role of NPK fertilization in promoting vegetative growth characters, enhancing yield component parameters and increasing yield and oil yield production, as well as stimulating the photosynthetic pigments and nitrogen, phosphorus and potassium content of savory plants could be explained by recognizing their fundamental involvement in the very large number of enzymatic reaction that depend on NPK fertilization. NPK reflected directly on increasing the content of chlorophyll a, b and carotenoids, as well as NPK \% and content in the leaves were indirectly the cause for enhancing the augmenting of all other vegetative growth traits, yield components and finally fruit as well as oil yield production of savory plants. The positive effect of NPK fertilization on nitrogen percentage in savory plant might be due to more absorption and accumulation of nitrogen. Similar results are found by Gad (2001), Hammoda (2001) on Glossostemon burguieri Desf., Batra et al. (2002), Al-Humaid (2004) on fennel, Bowes and Zheljazkov (2004), El-Khayat and Gouda (2005) and Tunio et al. (2005). This increment may be due to the availability of nitrogen for plant absorption and /or translocation of nitrogen from the root to the above ground parts. In this respect, Hamed (2004) mentioned that the highest values of $\mathrm{N}$ in the herb were recorded for the treatment of biofertilizer plus full dose of $\mathrm{N}$ and $\mathrm{P}$ than the other treatments and control plants.

Biofertilizer product containing nitrogen fixing bacteria, e.g. Azotobacter and Azospirillum was found to have not only the ability to fix nitrogen, but also to release certain phytohormones of gibberellins and indolic nature, which could enhance plant growth absorption of nutrients and so on photosynthesis process (Hegde et al., 1999). Microorganisms used as biofertilizers may affect their host plant by one mechanism or more; such as nitrogen fixation, production of growth promoting substances or organic acids, enhancing nutrients uptake or protection against plant pathogens (Hawaka, 2000). Also, N-fixers synthesize stimulatory compounds such as; gibberellins, cytokinins and IAA. They act as growth regulators, which increased the surface area per unit of root length and were responsible for root hair branching with an eventual increase in the uptake of nutrients from the soil (Sperenat,1990; Dadarwal et al., 1997 and Glick, 2003).

Moreover, biofertilizer product containing very active phoshphate dissolving bacteria has proved its efficiency in enhancing different aspects of 
plant growth and development of many plant species including medicinal and aromatic plants. Establishment of a strong root system is related to the level of available phosphate in the soil (Abou El-Hassan et al., 1993). Phosphate dissolvers or vesicular arbuscular mycorrhizae and silica bacteria are capable of converting tricalcium phosphate to monocalcium phosphate ready for plant nutrition (Ali et al., 1987; El-Gibaly et al., 1997; Abd-Alla 1998 and Hawaka, 2000). Phosphate also increased mineral uptake and water use efficiency (El-Awag et al., 1993). Under the Egyptian soil conditions, Brown (1974), Abo El-Nour et al. (1996) and El-Sheekh (1997) mentioned that using biofertilizer apparently increased the available phosphate fertilizer concentration in the soil and plants.

This result is logical, because such biofertilizer with the added amount cannot meet the plant nutritional requirements in such sandy soil, which is very poor in organic matter, but can be appreciated when used with adequate amount of chemical fertilizer to decrease the harmful effect of such biofertilizer and/or its costs. In this regard, there was an agreement with several investigators working on chemical and biofertilizer on some medicinal and aromatic plants; i.e. Eid and El Ghawwas (2002), El-Sayed et al. (2002) and Mohsen (2002) on sweet basil, Kandeel and Sharaf (2003), Mahfouz (2003), Hamed (2004) on Salvia officinalis and Origanum syriacum, Toaima (2005) on Achillea millefolium, Mahfouz and Sharaf Eldin (2007) on fennel, Swaefy et al. (2007) on peppermint, Gharib et al. (2008) on marjoram and Leithy (2009) on geranium.

\section{REFERENCES}

Abd-Alla, S.S.A. (1998). Response of maize to nitrogen and bio-fertilizer. Assuit J. Agric. Sci., 29 (1): 59-73.

Abo El-Ala, H.K. (2002). Biofertilization techniques used for improving production of some medicinal plants in desert soil. Ph.D. Thesis, Institute of Environmental Studies and Research, Ain Shams Univ., Cairo, Egypt.

Abou El- Hassan, A., A.H. Shahien and M.S. Youssef (1993). Effect of nitrogen and phosphorus fertilizers on some cultivars of bean plant. I. Morphological characters, yield and pod characteristics. Annals Agric. Sci., Moshtohor, 35: 265-271.

Abo El-Nour, E.A.A., A.A. El-Sayed, and A.A. El-Bendary (1996). Effect of phosphate bio-fertilizer (phosphorein) on growth, yield and nutrient uptake of faba bean plants. J. Agric. Sci., Mansoura Univ., 21 (2): 477-483.

Adams, R.P. (2007). In "Identification of Essential Oil Components by Gas Chromatography/Mass Spectroscopy". Allured, Carol Stream, Illinois, and USA.

Egyptian J. Desert Res., 65, No. 1, 101-123 (2015) 
Al-Humaid, A.L. (2004). Effect of bio and chemical fertilizers on the growth and essential oil yield of fennel (Foeniculum vulgare Mill.). Alex. J. Agric. Res., 49 (3): 83-91.

Ali, M.E., A.M. Massoud and I.A.I. El-Gandor (1987). Effect of different isolates of phosphate dissolving bacteria PDB on soil $\mathrm{pH}$ and soil available phosphorus. Cand. J. Microbiol., 45: 197-201.

A.O.A.C. (1970). In "Official Methods of Analysis of Association of Official Agriculture Chemists". Washington, D. C., $10^{\text {th }} \mathrm{ed}$.

Arabaci, O. and E. Bayram (2004). The effect of nitrogen fertilization and different plant densities on some agronomic and technologic characteristic of Ocimum basilicum L. (basil). J. Agro., 3: 255-262.

Baher, Z.F., M. Mirza, M. Ghorbanli and M. Rezaii (2002). The influence of water stress on plant height, herbal and essential oil yield and composition in Satureja hortensis L. Flav. Frag. J., 17: 275-277.

Baser, K.H.C., M. Kürkçüoglu, B. Demirci and T. Özek (2003). The essential oil of Origanum syriacum, var. Sinacum (Bioss) lets Wart. Flavour and Fragrance Journal, 18 (2): 98-99. John Wiley and Sons, Chichester, UK.

Baser, K.H.C., T. Ozek, N. Kirimer and G. Tumen (2004). Comperative study of the essential oils of wild and cultivated Satureja hortensis L. J. Essen. Oil Reas., 6: 422-424.

Batra, V.K., V.P. Mohan, K.K. Thkaral and A.K. Bhatia (2002). Seed yield and quality of fennel as influenced by date of sowing and seed rate. Haryana Journal of Horticultural Sciences, 31 (1/2): 111113. Horticultural Society of Haryana, Hisar, India.

Baydar, H., O. Sagdic, G. Ozkan and T. Karadogan (2004). Antibacterial activity and composition of essential oils from Origanum, Thymbra and Satureja species with commercial importance in Turkey. Food Cont., 15: 169-172.

Bedwell, R.G.S. (1974). In "Plant Physiology". MacMillan, New York.

Bowes, K.M. and V.D. Zhelijazkov (2004). Essential oil yields and quality of fennel grown in Nova Scotia. HortScience, 39 (7), 1640-1643. American Society for Horticultural Science, Alexandria, USA.

Boyraz, N. and M. Özcan (2006). Inhibition of phytopathogenic fungi by essential oil, hydrosol, ground material and extract of summer savory (Satureja hortensis L.) growing wild in Turkey, Inter. J. Food Microbiol., 107: 238-242.

British Pharmacopoeia (1963). In "Determination of Volatile Oil in Drugs". The Pharmaceutical Press, London.

Brown, M.E. (1974). Seed and root bacterization. Ann. Rev. Phytopathol., 12: $181-197$.

Cooke, G.W. (1982). In "Fertilizing for Maximum Yield". Third Edition, Granada Publishing Limited. 
Costat (1986). Software Program for The Design and Analysis of Agronomic Research Experiments. Chort. Software, Costat 3-30, Berkeley, CA., U.S.A.C.F.

Cottenie, A., M. Verloo, M. Velghe and R. Camerlynck (1982). In "Chemical Analysis of Plant and Soil". Laboratory of Analytical and Agrochemistry. State Univ. Ghent, Belgium.

Chapman, H.D. and P.F. Pratt (1961). In "Methods of Analysis for Soils". Plant and Water Div. of Agric. Sci., Univ. of Calif., 309 pp.

Dadarwal, L.R., L.S. Yadav and S.S. Sindhu (1997). In "Bio-fertilizer Production Technology: Prospects". Biotechnological approaches: In Soil Microorganisms for Sustainable Crop Production. P. 323337. Scientific Publisher, Jodhpur, India.

Dart, P.J. (1986). Nitrogen fixation associated with non-legumes in agriculture. Plant Soil, 90: 303-334.

Deans, S.G. and G. Ritchie (1987). Antibacterial properties of plant essential oils. Int. J. Food Microbiol., 5: 165-180.

Devlin, R.M. (1972). In "Plant Physiology". Third Edition. Van Nostrand Company, New York.

Dorman, H.J.D. and R. Hiltunen (2004). Fe (III) reductive and free radicalscavenging properties of summer savory (Satureja hortensis L.) extract and subfractions. Food Chem., 88: 193-199.

Economakis, C. (2005). Effects of solution conductivity on the volatile oil constituents of Origanum dictamnus L. in nutrient film culture. J. Agric. Food Chem., 53: 1656-1660.

Eid, M.I. and E.O. El-Ghawwas (2002). Study on the responsibility of marjoram plant to biofertilizer in sandy soil. Egypt. J. Appl. Sci., 17 (3): 163-175.

El-Merich, C., M. De-Zamarozy, F. Arsene, T. Pereg, A. Paquellin and A. Kaminski (1997). Regulation of NIF gene expression and nitrogen metabolism in Azospirillum. Soil Biol. Biochem., 29 (5-6): 847852.

El-Awag, I.I., A.M. Hanna and I.M. El-Naggar (1993). Influence of bio and mineral phosphate fertilization on soybean production and some water characters under different levels of soil moisture. Egypt. J. Appl. Sci., 8 (11): 575-594.

El-Gibaly, M.H., F. M. El-Rewing, M. Abdel Nasser and T.H. El-Dahtory (1997). Studies on phospholubilizing bacteria in soil and rhizosphere of different plants. 1- Selection of the most efficient phosphate dissolving and their microphological grouping. 261, BaK 11, Abst. Bd., 132: 240-244.

El-Sayed, A.A., M.A. Sidky Mansure and M.A. Mohesn (2002). Response of basil (Ocimum basilicum L.) to different chemical and organic fertilization treatments. J. Agric. Sci., Mansoura Univ., 28 (2): 1401-1418.

Egyptian J. Desert Res., 65, No. 1, 101-123 (2015) 
El-SheeKh, H.M. (1997). Effect of bio and mineral phosphate fertilizers on growth, yield, quality and storeability of onion. Egypt. J Appl. Sci., 12 (12): 213-231.

Gad, W.M. (2001). Physiological studies on Foeniculum vulgare Mill. and Anethum graveolens L. M.Sc. Thesis., Fac. Agric., Kafr ElSheikh, Tanta Univ., Egypt.

Gaur, A.C. and K.P. Ostwal (1972). Influence of phosphate dissolving bacilli on yield and phosphate uptake of wheat crop. Indian $\mathbf{J}$. Exptl. Biol., 10: 393.

Gharib, Fatma A., Lobna A. Moussa and O. Massoud (2008). Effect of compost and bio-fertilizers on growth, yield and essential oil of sweet marjoram (Majorana hortensis). Plant International Journal of Agriculture and Biology, 10 (4): 381-387.

Glick, B.R. (2003). In "Plant Growth Promoting Bacteria". Glick, B.R. and J.J. Pasternak (eds.). Molecular Biology-Principles and Applications of Recombinant DNA, ASM Press, Washington DC, USA.

Goldstein, A.H. (1986). Bacterial solubilization of mineral phosphates: historical perspective and future prospects. Am. J. Altern. Agric., 1: 51-57.

Gulluce, M., M. Sokmen, D. Daferera, G. Agar, H. Ozkan and N. Kartal (2003). In vitro antibacterial, antifungal and antioxidant activities of the essential oil and methanol extracts of herbal parts and callus cultures of Satureja hortensis L. J. Agric. Food Chem., 51: 39583965.

Hach, C.C., S.V. Brayton and A.B. Kapelove (1985). Powerful kejeldah nitrogen method using peroxy mono sulfuric acid. J. Agric. Food Chem., 33: 1117-1123.

Hamed, E.S. (2004). Studies on planting of some medicinal plants in the desert. M.Sc. Thesis, Fac. Agric., Kafr El-Sheikh, Tanta Univ., Egypt.

Hammoda, S.S. (2001). Effect of some agricultural treatments on growth and productivity of moghat plant under Sinai conditions. M.Sc. Thesis, Fac. Agric., Cairo Univ., Egypt.

Hawaka, F.I.A. (2000). Effect of using single and composite inoculation with Azospirillum brasilense, Bacillus megatherium var. phosphaticum and Glomus macrocarpus for improving growth of Zea mays. J. Agric. Sci. Mansoura, Egypt, 32 (12): 239-252.

Hegde, D.M., B.S. Dwivedi and S.S. Sudhakara Babu (1999). Biofertilizers for cereal production in India. A review. Ind. J. Agric. Res., 69 (2): 73-83.

Herbert, D., P.J. Philips and R.E. Strange (1971). Determination of total carbohydrates. Methods in Microbiology, 58: 209-344. 
Inouye, S., T. Takizawa and H. Yamaguchi (2001). Antibacterial activity of essential oils and their major constituents against respiratory tract pathogens by gaseous contact. J. Antimicrob. Chemother., 47:565573.

Kandeel, A.M. and M.S. Sharaf (2003). Productivity of Majorana hortensis, Moench. plants as influenced by the interactions between mineral and biological fertilization. J. Agric., Sci., Mansoura Univ., 28(2): 1373-1389.

Kapoor, R., B. Giri and K.G.Mukerji (2004). Improved growth and essential oil yield and quality in Foeniculum vulgare Mill. on mycorrhizal inoculation supplemented with P-fertilizer. Biores. Technol., 93: 307-311.

Khalid, Kh.A., S.F. Hendawy and E. El-Gezawy (2006). Ocimum basilicum L. production under organic farming. Res. J. Agri. Biol. Sci., 2: 25-32.

El-Khayat, A.S and H.A. Gouda. (2005). Effect of sowing date and potassium fertilization on growth, yield and chemical composition of Foeniculum vulgare, Mill plants. Annals of Agricultural Science, Moshtohor, 43 (3): 1245-1269.

Klaric, S.M., I. Kosalec, J. Mastelic, E. Pieckova and S. Pepeljnak (2007). Antifungal activity of thyme (Thymus vulgaris L.) essential oil and thymol against moulds from damp dwellings. Lett. Appl. Microbiol., 44: 36-42.

Kulisic, T., A. Radonic and M. Milos (2005). Antioxidant properties of thyme (Thymus vulgaris L.) and wild thyme. Italian J. Food Sci., 17: 315-324.

Lambers, H., F.S. Chapin and T.L. Pons (2000). Plant Physiological Ecology. Springer-Verleg, New York Inc.

Leithy, S., M.S. Gaballah and A.M. Gomaa (2009). Associative impact of bio- and organic fertilizers on geranium plants grown under saline conditions. Inter. J. Acad. Res., 1(1): 17-23.

Mahfouz, S.A. (2003). Effect of biofertilization on growth and oil production of marjoram (Majorana hortensis L.). Ph. D. Thesis, Fac. Agric., Cairo Univ., Egypt.

Mahfouz, S.A. and M.A. Sharaf El-din (2007). Effect of mineral vs. biofertilizer on growth, yield and essential oil content on fennel (Foeniculum vulgare Mill.). Int. Agrophysics, 21 (4): 361-366.

Mengel, K. and A. Kirkby (1987). In "Principles of Plant Nutrition". $4^{\text {th }}$ Edition. International Potash Institute, Bern, Switzerland.

Mohsen, M.M. (2002). Sweet basil herb and oil production as affected by chemical and organic fertilization. M.Sc., Thesis, Fac. Agric. Cairo Univ. 
Murphy, J. and J.H. Riley (1962). A modified single solution for the determination of phosphate in natural waters. Ann. Chem. Acta, 27: 31-36.

Naghdibadi, H., D. Yazdani, S. Mohammad Ali and F. Nazari (2004). Effects of spacing and harvesting time on herbage yield and quality/quantity of oil in thyme (Thymus vulgaris L.). Indust. Crops Prod., 19: 231-236.

Nguyen, P.M. and E.D. Niemeyer (2008). Effect of nitrogen fertilization on the phenolic composition and antioxidant properties of basil (Ocimum basilicum L.). J. Agric. Food Chem., 56 (18): 8685-8691.

Novak, J., L. Bahoo, U. Mitteregger and Ch. Franz (2006). Composition of individual essential oil glands of savory (Satureja hortensis L., Lamiaceae) from Syria. Flav. Frag. J., 21: 731-734.

Osman, Y.A.H (2000). Possibility of production of coriander (Coriander sativum L.) under Sinai conditions. Ph.D. Thesis, Fac. Agric., Cairo University.

Rai, S.K., R.S. Katiyar and S.P. Singh (2002). Effect of nitrogen and phosphorus on the growth and yield of Foeniculum vulgare, Mill. on the sodic soil. Journal of Medicinal and Aromatic Plant Sciences, 24 (1): 65-67.

Ravid, U. and E. Putievsky (1986). In "Carvacrol and Thymol Chemotype of East Mediteranian Wild Labiatae Herbs". Progress in Essential Oil Research, p. 163-167. Walter de Gryter Co., Berlin, Germany.

Reda, F., E.A. Abdel Rahim, G.S.A. El Baroty, H.S. Ayad (2005). Response of essential oils, phenolic components and polyphenol oxidase activity of thyme (Thymus vulgaris L.) to some bioregulators and vitamins. J. Agr. Biol., 7: 735-739.

Said Al Ahl, H.A.H., S.A. Hasnaa and S.F. Hendawy (2009). Effect of potassium humate and nitrogen fertilizer on herb and essential oil of oregano under different irrigation intervals. Journal of Applied Sciences, 2 (3).

Sefidkon, F., K. Abbasi and G.B. Khaniki (2006). Influence of drying and extraction methods on yield and chemical composition of the essential oil of Satureja hortensis. Food Chemistry, 99: 19-23.

Sell, C.S. (2003). In "A Fragrant Introduction to Terpenoid Chemistry". The Royal Society of Chemistry, Thomas Graham House, Science Park, Milton Road, Cambridge, UK.

Shahram S. and O. Kourosh (2011). Organic and bio-fertilizers as a good substitute for inorganic fertilizers in medicinal plants farming. Australian Journal of Basic and Applied Sciences, 5(12): 13301333.

Sharafzadeh, Sh. (2011). Effect of nitrogen, phosphorus and potassium on growth, essential oil and total phenolic content of garden thyme (Thymus vulgaris L.). Adv. Environ. Boil., 5: 699-703. 
Snedecor, G.W. and W.G. Cochran (1968). In "Statistical Methods". Sixth Edition. The Iowa State Univ. Press, Ames, Iowa, U.S.A.

Sperenat, M. (1990). In "Nitrogen Fixing Organisms". Chapman and Hall, London.

Svoboda, K.P., R.K.M. Hay and P.G. Waterman (2006). Growing summer savory (Satureja hortensis) in Scotland: Quantitative and qualitative analysis of the volatile oil and factors influencing oil production. J. Sci. Food Agri., 53: 193-202.

Swaefy, H.M.F., W.R.A. Saker, A.Z. S and A.A. Ragab (2007). Effect of some chemical and bio-fertilizers on peppermint plants grown in sandy soil. Annals Agric. Sci., Ain Shams Univ., Cairo, 52 (2): 451-463.

Thompsond, L.M. and F.R. Troeh (1975). In "Soils and Soil Fertility". TATA Mc-Graw-Hill Pub. Co. Ltd., New Delhi.

Toaima, I.M.W. (2005). Production of yarrow (Achillea millefolium L.) under Sinai conditions. M.Sc. Thesis, Fac. Agric., Al-Azhar Univ.

Tunio, S.D., H.I. Majeedano, M.S. Jogi and A.D. Jarwar (2005). Effect of different sowing dates on growth and yield of fennel. Pakistan Journal of Agriculture, Agricultural Engineering, Veterinary Sciences, 21 (2): 7-10. 


\title{
تأثير التسميد الكيماوى والحيوي على نمو وإنتاجية نباتات السافوري
}

\author{
وفاء حامد عبد الله \\ قسم النباتات الطبية و العطرية، مركز بحوث الصحر اء، القاهرة، مصر
}

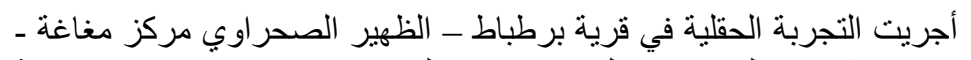

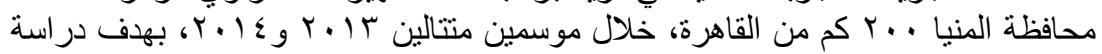

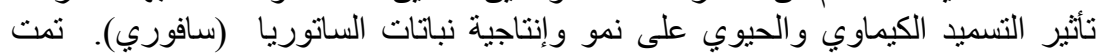

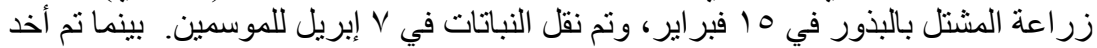

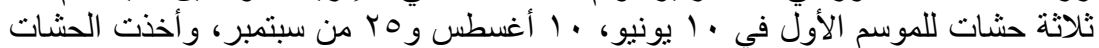

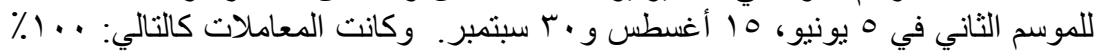

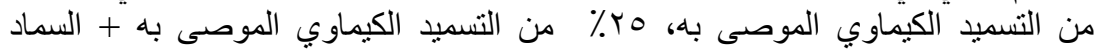

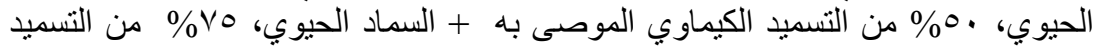

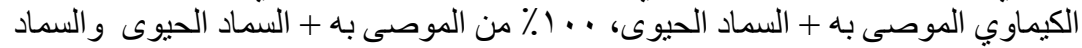

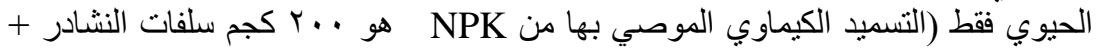

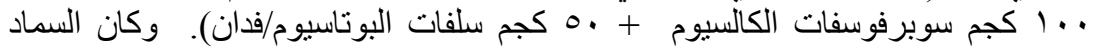

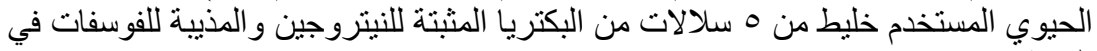

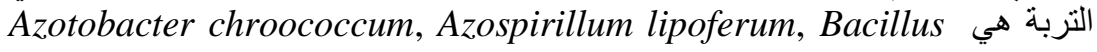
polymixa, Bacillus megatherium and Pseudomonas fluorescence

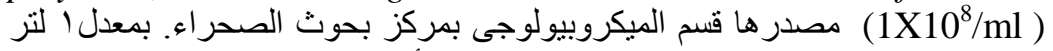

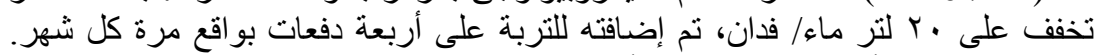

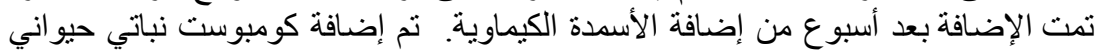

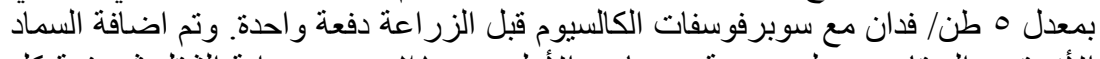

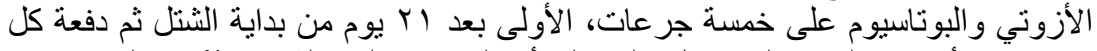

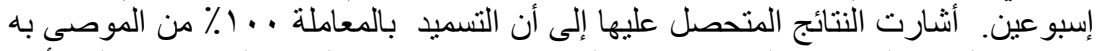

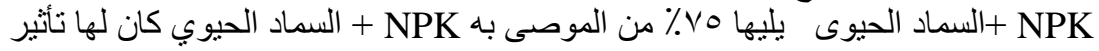

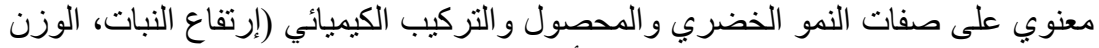

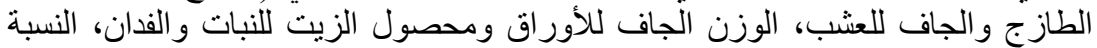

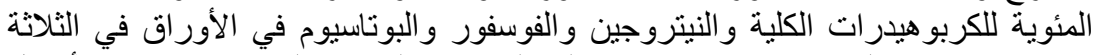

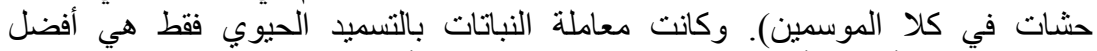

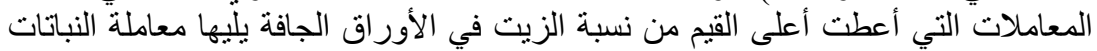

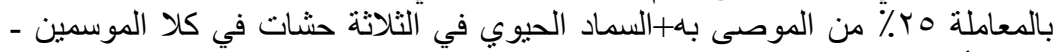

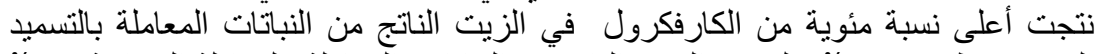

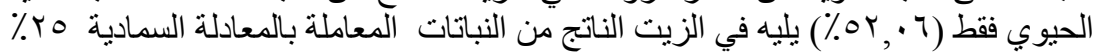

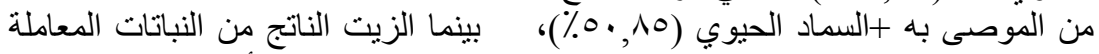

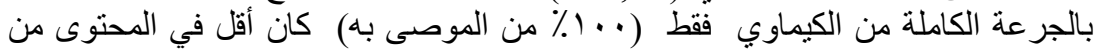

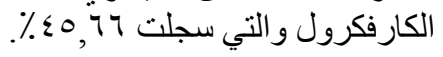

Egyptian J. Desert Res., 65, No. 1, 101-123 (2015) 